\title{
PHYSICAL EFFICIENCY TESTS IN INDIAN URBAN ADOLESCENT BOYS AND GIRLS
}

\author{
${ }^{*}$ A. K. DE, MB, BS, DCH, MD, * ${ }^{*}$ P. DEBNATH, BSc, MEd(Phy) \\ ** J. NAGCHAUDHURI, BSc(Hons), MB, BS, PhD(Lond)
* and ** Unit of Sports Medicine and Pulmonary Physiology, Department of Physiology, Institute of Medical Sciences, Banaras Hindu University, Varanasi-221005, India
**Department of Physical Education, National Council of Education, Jadavpur University, Calcutta-700032, India

\begin{abstract}
Simple anthropometric measurements and physical efficiency tests were performed on adolescent Indian urban boys between 10-14 years and girls between 11-14 years of age. The similar height and weight of the subjects of both sexes were observed and was suggestive of higher growth rate in girls than the boys during only the initial phase of adolescent growth spurt. The vital capacity (total, $\mathrm{ml} / \mathrm{cm}$ of height, I/ $\mathrm{m}^{2}$ of surface area), Peak Expiratory Flow Rate (total, I/cm of height, $1 / \mathrm{kg}$ of weight, $1 / \mathrm{m}^{2}$ of surface area, I/year of age) and grip strength were observed to be insignificantly different between the sexes.
\end{abstract}

Key Words:

Urban adolescents, physical efficiency, simple anthropometry, vital capacity, peak expiratory flow rate, grip strength.

The adolescents are considered as one of the vulnerable population groups owing to their peculiar physiological states (De and Nagchaudhuri, 1976a; Shock, 1943a, 1946b). A considerable number of physiological changes occur during this period. Among the significant changes, some are well-documented; increased rate of growth, rise in the systolic blood pressure, lowering in heart rate, comparative increase of the basal metabolic rate etc. (Boas, 1930, 1932; Shuttleworth, 1937, 1939; Simmons and Gruelich, 1943). These changes are more closely related to the adolescent growth spurt and to the maturity of the reproductive capacity than to the chronological age. Various other factors like physique, season of the year, nutrition and socio-economic status influence the interrelationship genetic and environmental effects throughout the whole period of adolescence (Tanner, 1964).

It is well-known that onset of the adolescent growth spurt in girls occurs earlier and continues for a shorter duration, than in boys (Du-Bois, 1929; Boothby and

Address for correspondence:

Dr. A. K. De, MBBS, DCH, MD, DipSports Med, AFIMS

Unit of Sports Medicine and Pulmonary Physiology,

Department of Physiology,

Institute of Medical Sciences,

Banaras Hindu University,

Varanasi-221005, India
Sandeford, 1929; Topper and Mulier, 1932; Dakshayani and Ramanamurthy et al, 1962; De and Nagchaudhuri, 1975; Shock, 1946a). The present study was undertaken to compare some aspects of physical fitness/efficiency during the initial phase of adolescent growth spurt between boys and girls in an Indian urban community.

\section{MATERIALS AND METHODS}

Eighteen Bengalee boys and sixteen girls from the urban school (Jadavpur, Calcutta, West Bengal, India) were selected for this study. The subjects were from an income range between Rupees 1,200/- to 1,500/- per month. The questionnaire method of diet survey was suggestive of better calorie/protein intake of these subjects in comparison to those of the comparatively poorer section of Bengalee families. The age of the boys ranged from 10-14 years and the girls from 11-14 years. The height and weight of the subjects were noted. The vital capacity (VC) was recorded using Wright's Respirometer, the Peak Expiratory Flow Rate (PEF) with the help of Wright's Peak Flowmeter and the Grip Strength by Hand Dynamometer.

Growth performance of well-to-do Indian children with a follow up study were shown to be comparable to those of American children between 3 to 13 years of age (Vijayaraghavan, Singh et al, 1971; Vijayaraghavan, Sastry et al, 1971; Khan and Belavady, 1973). The subjects of the present investigation were also from a similar socio-economic status of different part of India. Du Bois nomogram, therefore, is applicable to determine the surface area of these subjects of both sexes, and was used for these subjects. 


\section{RESULTS AND DISCUSSION}

The results are summarised in Table I. The records of height and weight of the experimental subjects providing information on the growth processes shows both boys and girls have attained similar physical growth, during the initial phase of adolescence. The consequent changes in surface area are also given.

\section{TABLE I}

Indian adolescents;

physical characteristics and respiratory efficiency.

\begin{tabular}{|c|c|c|}
\hline & $\begin{array}{l}\text { BOYS } \\
N=18\end{array}$ & $\begin{array}{l}\text { GIRLS } \\
N=16\end{array}$ \\
\hline $\begin{array}{l}\text { AGE (years) - range } \\
\text { mean } \& \pm \text { S.D. }\end{array}$ & $\begin{array}{l}10-14 \\
12.11 \pm 1.1\end{array}$ & $\begin{array}{l}11-14 \\
12.1 \pm 0.9\end{array}$ \\
\hline HEIGHT (cms) & $\begin{array}{l}139-170 \\
149.5 \pm 9.1\end{array}$ & $\begin{array}{l}134-158 \\
148.4 \pm 6.3\end{array}$ \\
\hline WEIGHT (kg) & $\begin{array}{l}25.5-51.0 \\
35.7 \pm 7.0\end{array}$ & $\begin{array}{l}23.0-46.0 \\
35.9 \pm 6.4\end{array}$ \\
\hline SURFACE AREA $\left(\mathrm{m}^{2}\right)$ & $\begin{array}{l}1.04-1.58 \\
1.24 \pm 0.15\end{array}$ & $\begin{array}{l}0.95-1.42 \\
1.23 \pm 0.12\end{array}$ \\
\hline $\begin{array}{r}\text { GRIP STRENGTH (kg) } \\
\text { RIGHT }\end{array}$ & $\begin{array}{l}12-40 \\
19.5 \pm 7.5\end{array}$ & $\begin{array}{l}11-26 \\
18.0 \pm 4.2\end{array}$ \\
\hline $\begin{array}{r}\text { GRIP STRENGTH }(\mathrm{kg}) \\
\text { LEFT }\end{array}$ & $\begin{array}{l}11-32 \\
17.00 \pm 6.8\end{array}$ & $\begin{array}{l}10-23 \\
16.7 \pm 4.3\end{array}$ \\
\hline VITAL CAPACITY (litres) & $\begin{array}{l}1.80-3.40 \\
2.41 \pm 0.46\end{array}$ & $\begin{array}{l}1.25-2.84 \\
2.17 \pm 0.44\end{array}$ \\
\hline $\mathrm{VC}$ as $\mathrm{ml} / \mathrm{cm}$ height & $\begin{array}{l}12.95-21.93 \\
16.04 \pm 2.32\end{array}$ & $\begin{array}{r}8.80-18.93 \\
14.55 \pm 2.72\end{array}$ \\
\hline$V C$ as $L / m^{2}$ surface area & $\begin{array}{l}1.67-2.48 \\
1.94 \pm 0.22\end{array}$ & $\begin{array}{l}1.18-2.05 \\
1.73 \pm 0.23\end{array}$ \\
\hline $\begin{array}{r}\text { PEAK EXPIRATORY FLOW } \\
(\mathrm{L} / \mathrm{min})\end{array}$ & $\begin{array}{l}235 \cdot 465 \\
351 \pm 69\end{array}$ & $\begin{array}{l}210-430 \\
323 \pm 64\end{array}$ \\
\hline PEF as L/cm height & $\begin{array}{l}1.70-2.93 \\
2.34 \pm 0.4\end{array}$ & $\begin{array}{l}1.40-2.20 \\
2.17 \pm 0.4\end{array}$ \\
\hline PEF as L/kg weight & $\begin{array}{l}7.38-12.76 \\
9.92 \pm 1.4\end{array}$ & $\begin{array}{l}6.40-12.4 \\
9.12 \pm 1.7\end{array}$ \\
\hline PEF as $L / m^{2}$ surface area & $\begin{array}{l}225 \cdot 349 \\
284 \pm 40\end{array}$ & $\begin{array}{l}177-338 \\
263 \pm 44\end{array}$ \\
\hline PEF as L/age in years & $\begin{array}{l}22.9-35.8 \\
28.9 \pm 4.3\end{array}$ & $\begin{array}{l}17.5-35.0 \\
26.7 \pm 5.2\end{array}$ \\
\hline
\end{tabular}

The characteristics of respiration change during adolescence. The rate of respiration during basal conditions is known to decrease steadily throughout childhood and a similar trend continues during puberty, without show- ing any sex difference (lliff and Lee, 1952). Shock (1946a, 1946b) has reported that resting respiratory minute volume increased considerably in boys, and very little, if at all, in girls. The present study indicates that there was no significant difference of the observed values of vital capacity (VC) between boys and girls, similarly VC when expressed in $\mathrm{ml} / \mathrm{cm}$ of height was not significantly different. Further, the VC even when presented in terms of $1 /$ unit of surface area $\left(\mathrm{m}^{2}\right)$ was also not significantly different.

There was no significant difference in the PEF values between the boys and girls. The PEF values expressed as $1 / \mathrm{min} / \mathrm{cm}$ height, $1 / \mathrm{kg}$ of weight, $1 / \mathrm{min} / \mathrm{m}^{2}$ surface area or, $1 / \mathrm{min} /$ age were all found to be insignificantly different (Burr, Eldridge et al, 1974). Although the reports in the literature showed that the boys had higher values of vital capacity, maximum breathing capacity, inspiratory and expiratory flow rates than the girls during the period of adolescence (Åstrand, 1952; Ferris and Whittenberger et al, 1952; Ferris and Smith, 1953; Kennedy and Thursby-Pelham et al, 1957), the studies were conducted on the population of different socio-economic status. The findings in the present study that the VC and PEF values were not different during the early period of adolescence in both the sexes, might be due to the fact that the subjects were selected from only a specific comparable socio-economic group.

The muscles of the adolescents not only increase in size but also gain proportionately in strength. The early reports regarding the strength gain tests, hand grip, arm pull and arm thrust had shown a more marked adolescent spurt in boys than in girls. However, this spurt was observed among the boys from the age of 13-16 years for all the strength tests, whereas a less definite spurt was seen in the case of girls between $12-13 \frac{1}{2}$ years, when the grip strength test was taken as an index (Schlesinger, 1934; Bookwalter, 1950; Cullumbine and Bibile et al, 1950). Our results using hand dynamometer for measuring the grip strength showed that the boys did not have a better strength gain than the girls.

Since the onset of puberty occurs earlier and early growth rate is faster in girls than in boys (Patwardhan, 1956; Phansalkar and Patwardhan, 1956; Rao and Pasricha et al, 1958; De and Nagchaudhuri, 1976a, b; Banerjee and Bhattacharya, 1964; Shock, loc. cit.), the observed values of height and weight of both the sexes were very close to each other. The similar values of different physical efficiency tests as observed for boys and girls during the initial phase of adolescence may thus be explained.

\section{REFERENCES}

Åstrand, P. O., 1952. "Experimental studies of physical working capacity in relation to sex and age". Munksgaard, Copenhagen. 
Banerjee, S. and Bhattacharya, A. K., 1964. "Basal metabolic rate of boys and young adults of Rajasthan". Indian J.Med.Res. 52: 1167-72.

Boas, F., 1930. "Observations on the growth of children". Science 72: 40-48.

Boas, F., 1932. "Studies in growth". Hum.Biol. 4: 307-50.

Bookwalter, K. W., 1950. “Grip strength norms for males". Res.Quart. 21: 249-73.

Boothby, W. M. and Sandeford, 1., 1929. "Normal values of basal or standard metabolism, modification of the Du-Bois standards". Am.J.Physiol. 90: 290-91.

Burr, M. L., Eldridge,.B. A. and Borysiewicz, L. K., 1974. "Peak expiratory flow rates before and after exercise". Arch.Dis.Child 49: 923-26.

Cullumbine, H., Bibile, S. W., Wikramanayake, T. W. and Watson, R. S., 1950. "Influence of age, sex, physique and muscular development on physical fitness". J.Appl.Physiol. 2: 488-511.

Dakshayani, R., Ramanamurthy, P. S. V. and Srikantia, S. G., 1962. "Body composition and basal metabolism of normal Indian women". Indian J.Med.Res. 50: 800-803.

Dakshayani, R. and Ramanamurthy, P. S. V., 1964. "Basal metabolism and creatinine excretion in different physiological groups". Indian J.Med.Res. 52: 1159-66.

De, A. K. and Nagchaudhuri, J., 1975. "Studies on the basal metabolic rate (BMR) - pregnant and lactating women in Varanasi". Indian J.Med.Res. 63: 613-16.

De, A. K. and Nagchaudhuri, J., 1976a. "Studies on the basal metabolic rate - boys and girls in Varanasi". Indian J.Med.Res. 64: 584-89.

De, A. K. and Nagchaudhuri, J., 1976b. "Blood ketoacids and its relation to respiratory quotient". Indian J.Physiol. Pharmacol. 20: 231-34.

Du-Bois, E. F., 1929. "Basal metabolism in health and disease". Lea and Febiger, Philadelphia.

Ferris, B. G. and Smith, C. W., 1953. "Maximum breathing capacity and vital capacity in female children and adolescents". Pediatrics 12: 341-352.

Ferris, B. G., Whittenberger, J. L. and Gallagher, J. R., 1952. "Maximum breathing capacity and vital capacity of male children and adolescents". Pediatrics 9: 659-70.

Iliff, A. and Lee, V. A., 1952. "Pulse rate, respiration rate and body temperature of children between two months and eighteen years of age". Child Develpm. 23: 237-45.

Kennedy, M. C. S., Thursby-Pelham, D. C. and Oldham, P. D., 1957. "Pulmonary function studies in normal boys". Arch.Dis.Childh. 32: 347-54.

Khan Latifa and Belavady Bhavani, 1973. "Basal metabolic rate in pregnant and nursing women and children". Indian J.Med.Res. 61: 1853-60.

Patwardhan, V. N., 1956. "Protein element in Indian nutrition". Indian J.Med.Sci. 10: 1-18.

Phansalkar, S. V. and Patwardhan, V. N., 1956. “Utilisation of animal and vegetable proteins: Nitrogen balances at marginal protein intakes and determination of minimum protein requirements for maintenance in young Indian men". Indian J.Med.Res.44: 1-10.

Rao, B. S. N., Pasricha, S. and Gopalan, C., 1958. "Nitrogen balance studies in poor Indian women during lactation". Indian J.Med.Res. 46: 325-31. 
Schlesinger, E., 1934. “Die Entwicklung de Korperkraft bei der heranwachsenden Jugend. Ihre Vitalcapazitat und Druckkraft". Z.Kinderheilk 56: 550-77.

Shock, N. W., 1943. "The effect of menarche on basal physiological function in girls". Am.J.Physiol. 139: 288-92.

Shock, N. W., 1946a. "Some physiological aspects of adolescence". Texas Rep.Biol.Med. 4: 289-310.

Shock, N. W., 1946b. "Physiological responses of adolescents to exercise". Texas Rep.Biol.Med. 4: 368-86.

Shuttleworth, F. K., 1937. "Sexual maturation and the physical growth of girls age six to nineteen". Monogr Soc.Res.Child Developm. 2: 253.

Shuttleworth, F. K., 1939. "The physical and mental growth of girls and boys age six to nineteen in relation to age at maximum growth". Monogr.Soc. Res.Child.Develop. 4: No. 3.

Simons, K. and Gruelich, W. W., 1943. "Menarcheal age and the height, weight and skeletal age of girls age 7 to 17 years". J. Pediat. 22: 518-48.

Tanner, J. M., 1964. “Growth at adolescence, 2nd Ed.". 156-75. Blackwell Scientific Publications, Oxford.

Topper, A. and Mulier, H., 1932. "Basal metabolism of normal children. The puberty reaction". Am.J.Dis.Child 43: 327-36.

Vijayaraghavan, K., Sastry, J. G. and Jindal, I. B., 1971. "Growth performance of well-to-do Hyderabad Children - a follow up study". Indian J.Med.Res. 62: 177-24.

Vijayaraghavan, K., Singh Darshan and Swaminathan, M. C., 1971. "Heights and weights of well-nourished Indian school children". Indian J.Med.Res. 59: 648-58.

NOTICE

\section{MEETING OF OTHER ORGANISATIONS - A.C.P.S.M. July 6 th -8 th, 1979}

The sixth Annual Residential Congress of the Association of Chartered Physiotherapists in Sports Medicine will take place in the University Hall, Cardiff from Friday, 6th to Sunday, 8th July, 1979. Following lunch at $12.30 \mathrm{hrs}$. the first symposium commences at 14.00 and includes papers on facial injuries in Rugby Football (R. Hopkins, B.D.S., M.R.C.S.) physiology of fitness (J. A. Fowler, M.C.S.P.) and applied kinesiology (B. M. Butler). A film on the 1978 Commonwealth Games will be shown at 20.30. On Saturday, 09.20 - Carbon filament replacement surgery (D. H. Jenkins, F.R.C.S.), interferential therapy (B. Savage, M.C.S.P.), functional aspects of throwing events (R. A. C. Davies, F.R.C.S.), therapeutic ultrasound (G. White, M.C.S.P.), and in the afternoon, 14.00, flexibility of the foot (S. Bracey, M.Ch.S.) strapping techniques (A. Bonelle, M.C.S.P.) and manual techniques in injury prevention and treatment (K. Slocombe, M.C.S.P.). The annual dinner (black ties) concludes the day's activities. On Sunday 09.00, doping in sport (provisional - speaker to be announced), impact therapy (J. B. Tracey, M.B., B.Ch.). The Annual General Meeting for members of A.C.P.S.M. ends the programme at 11.45 but lunch is available for those who give notice.

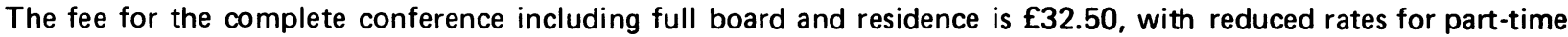
attendance, for students and for non-residents. Enquiries and applications for places should be sent as soon as possible to:-

Mr. J. R. Cross, M.C.S.P.,

8 Trinfield Avenue,

EXMOUTH.

Devon EX8 3JU.

Tel. Exmouth (03952) 75592 or 78406.

For members of A.C.P.S.M., application forms will be sent out in the next issue of Physiotherapy on Sport. 